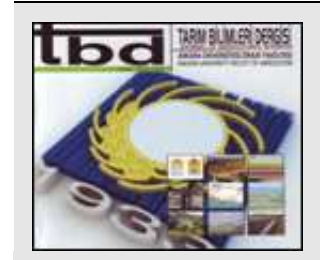

Tarım Bilimleri Dergisi

Journal of Agricultural Sciences

Tar. Bil. Der.

Dergi web sayfası:

www.agri.ankara.edu.tr/dergi

Journal homepage:

www.agri.ankara.edu.tr/journal

\title{
Postharvest Salicylic Acid Treatment Influences Some Quality Attributes in Air-Stored Pomegranate Fruit
}

\author{
Mert YILDIZ ${ }^{\mathrm{a}}$, Burak VARIS ${ }^{\mathrm{a}}$, Ozge HORZUM ${ }^{\mathrm{a}}$, Nurdan TUNA GUNES ${ }^{\mathrm{a}}$ \\ ${ }^{a}$ Ankara University, Faculty of Agriculture, Department of Horticulture, Ankara, TURKEY
}

\author{
ARTICLE INFO \\ Research Article \\ Corresponding Author: Nurdan TUNA GUNES, E-mail: tuna@agri.ankara.edu.tr, Tel: +90 (312) 5961320 \\ Received: 05 April 2019, Received in Revised Form: 29 July 2019, Accepted: 09 September 2019
}

AUTHORS ORCID ID:

(Mert YILDIZ: 0000-0003-3223-0639), (Burak VARIS: 0000-0002-0740-8258), (Ozge HORZUM: 0000-0003-2030-5613), (Nurdan TUNA GUNES: 0000-0002-8529-2211)

\section{ABSTRACT}

Popularity of pomegranate fruit has increased in recent years because of its health benefit content, economic value and medicinal characteristics. Since pomegranate fruit is perishable species, prolonging storage life, keeping fruit quality during storage and marketing period with minimum quality and quantity loss after harvest are essential. Influence of salicylic acid treatments on some quality properties in 'Hicaznar' cultivar fruit were investigated in the current study. After harvest at commercial maturity, fruit were exposed to salicylic acid (SA) treatments. Controls (C1) were untreated. The other groups were dipped into a solution containing $0.01 \%$ Tween 20 (C2), $0.01 \%$ Tween $20+2 \mathrm{mM} \mathrm{SA}$ (SA1), and $0.01 \%$
\end{abstract}

Tween $20+4 \mathrm{mM}$ SA (SA2). Then fruit were stored at $5 \pm 1{ }^{\circ} \mathrm{C}$ temperature, $85-90 \%$ relative humidity for 120 days. Changes in fruit skin and aril color, soluble solids content, titratable acidity, weight loss and chilling injury rate total phenolic content, antioxidant activity were followed at 60 days intervals. Neither SA1 nor SA2 affected total phenolic content and antioxidant activity levels of fruit. But, both treatments helped to maintain $C^{*}$ values in arils and skin, titratable acidity and soluble solids content. Since SA2 treatment significantly reduced chilling injury symptoms during cold storage period of 120 days, it could be considered as promising postharvest technology.

Keywords: Punica granatum L.; Chilling injury; Antioxidant; Phenolics

\section{Introduction}

Pomegranate (Punica granatum L.) has been a traditional fruit cultivated for many years. Recent studies revealed the positive effects of pomegranate fruit on human health, especially because of its high antioxidant activity (Wang et al 2018). It is also rich in sugar, pectin, vitamin C, amino acids, mineral substances, fiber and phenolic compounds (Aviram et al 2000). Because of these properties, it has been considered as one of the functional foods in the world in recent years.

Pomegranate fruit have a non-climacteric respiration pattern (Kader 2006). Even if they have long storage period at the proper temperature, chilling injury, fungal decay and weight loss which are major limiting factors for long storage period, can cause fruit losses at an important rates. Chilling injury rates and low temperature sensitivity during cold storage mostly depend on cultivar. According to Kader et al (1984), 'Wonderful' cultivar fruit show chilling injury when it is stored at temperature lower than $5^{\circ} \mathrm{C}$ for longer periods and a storage temperature of $7{ }^{\circ} \mathrm{C}$ is recommended. Köksal (1989) reported that 'Gök Bahçe' cultivar retained its quality for 3 months when it was stored at $5{ }^{\circ} \mathrm{C}$. 'Hicaznar' fruit can be stored under cold storage conditions for 4 months (Candir et al 2018) and under controlled atmospheric conditions for 5 months (Koyuncu et al 2019) at $6{ }^{\circ} \mathrm{C}$ temperature. 
Besides storage temperature, modified atmosphere packaging (Selcuk \& Erkan 2015), chitosan coating (Candir et al 2018), putrescine, salicylic acid (Koyuncu et al 2019), heat (Mirdehghan et al 2007), oxalic acid (Sayyari et al 2010) and methyl jasmonate (Sayyari et al 2011) treatments were used to reduce physiological disorders and extend storage period in pomegranate fruit of different cultivars. The effect of these treatments mostly depended on concentration of treatment material, cultivar and storage temperature.

Salicylic acid (SA) is a naturally synthesized phenolic compound effecting plant growth and development (Shaarawi et al 2016). Raskin (1992) recognizes it as a plant hormone. It is considered as 'Generally Recognized As Safe' (GRAS) (Sayyari et al 2009). Due to its positive effects on plant stress tolerance, SA might increase fruit resistance to stress conditions such as low temperature, inappropriate atmospheric conditions etc. after harvest (Asghari \& Aghdam 2010; Sayyari et al 2017). Sayyari et al (2009; 2017) mentioned that this compound had a significant effect on preventing chilling injury symptoms such as aril and skin browning, on reducing ascorbic acid loss in fruit of 'Malas Saveh' and 'Mollar de Elche' pomegranate cultivars. Wang et al (2006) reported that SA treatments decreased chilling injury symptoms in peach fruit. Srivastava \& Dwivedi (2000) for banana fruit and Zhang et al (2003) for kiwifruit revealed that SA maintained flesh firmness by retarding ethylene production. According to Chan \& Tian (2006), it reduced the fungal decays in sweet cherry.

'Hicaznar' is the most famous pomegranate cultivar in Turkey with its sour-sweet taste and attractive dark red skin color. It can be stored up to late March at $6{ }^{\circ} \mathrm{C}$ temperature. There are few information concerning the effect of SA treatment on some fruit quality characteristics of 'Hicaznar' pomegranate cultivar during regular air cold storage conditions. It has been known that ecology has an important effect on fruit quality and keeping quality during postharvest period and storage. There are not any data on storage potential of pomegranates grown in Mersin province of Turkey. In the current research, effect of SA treatments at various concentrations on some fruit quality parameters in fruit of 'Hicaznar' cultivar grown in Mersin-Tarsus area was investigated during cold storage period of 120 days.

\section{Material and Methods}

\subsection{Fruit samples}

'Hicaznar' pomegranate fruit were harvested from commercial orchard in Mersin-Tarsus (36 $\left.55^{\circ} 57^{\prime \prime} \mathrm{N} 34^{\circ} 51^{\prime} 45^{\prime \prime} \mathrm{E}\right)$, Turkey at commercial harvest maturity. Immediately after harvest, fruit were transported to Ankara University Faculty of Agriculture Department of Horticulture Postharvest Physiology Laboratory by a cooled truck.

\subsection{SA treatments and storage conditions}

After selecting uniform fruit in respect of free from disease and pests, and mechanical damages, they were divided into 4 groups. Control (C1) group were stored without any treatment. The other groups were dipped into a solution containing 0.01\% Tween 20 (Merck 9005-64-5) (C2), 0.01\% Tween 20+2 mM SA (Merck 69-72-7) (SA1), 0.01\% Tween 20+4 mM SA (SA2) for $10 \mathrm{~min}$ at $20^{\circ} \mathrm{C}$, respectively. After allowing them to naturally dry under laboratory conditions, they were stored in air at $5 \pm 1{ }^{\circ} \mathrm{C}$ temperature and $85-90 \%$ relative humidity for 120 days. A storage temperature of $5{ }^{\circ} \mathrm{C}$ was selected in order to observe whether effect of different SA concentrations especially on chilling injury rate. Changes in some fruit quality parameters mentioned below were determined at two months intervals during storage period.

\subsection{Assessments}

Skin color was measured at three different points on equatorial surface of fruit. Aril color was determined at three points after cutting fruit from equatorial part with a colorimeter (CR-200 Minolta, Japan). Data were presented as hue $\left(h^{\circ}\right)$, chroma $\left(C^{*}\right)$ and $L^{*}$ (McGuire 1992).

Soluble solids content (SSC) was read by a digital abbe refractometer (Leica 10480, Germany) in fruit juices obtained after squeezing and filtering of arils with a Whatman filter paper.

After joining pomegranate juice of $3 \mathrm{~mL}$ with $50 \mathrm{~mL}$ distilled water, solution was titrated with $0.1 \mathrm{~N} \mathrm{NaOH}(\mathrm{Merck}$, 106462) until $\mathrm{pH}=8.1$ with an automatic titrator (Mettler Toledo DL 50 Graphix, USA) for titratable acidity (TA) measurements and the results were expressed as citric acid\%. 
For weight loss determinations, same fruit at all analysis dates were weighed with a scale (Mettler Toledo, USA) and this parameter was presented as percentage in respect of initial weight.

Chilling injury (CI) symptoms in fruit such as skin browning and pitting, aril and membrane browning were individually evaluated by naked eye. Fruit showing injury symptoms were rated to the total fruit number. The results were presented as percentage.

For the extraction of total phenolic content (TPC), arils of $5 \mathrm{~g}$ was taken from each replicate and homogenized with $10 \mathrm{~mL}$ acetone (80\%) (Merck, 100014) containing 0.2\% formic acid (Merck, 100264) for $2 \mathrm{~min}$ at $13500 \mathrm{rpm}$ in a homogenizer (Janke \& Kunkel, Ultraturrax 725). Then extracts were centrifuged (Sigma 3K30) at $14000 \mathrm{rpm}$ for $20 \mathrm{~min}$ at $0{ }^{\circ} \mathrm{C}$. This process was performed 2 times as in Selcuk \& Erkan (2015). Total phenolic content was determined according to the method of Spanos \& Wrolstad (1990) with slight modifications. A hundred $\mu \mathrm{L}$ extract, $900 \mu \mathrm{L}$ double deionized water and $5 \mathrm{~mL}$ diluted Folin-Ciocalteu reagent (Sigma, F-9252) were vortexed in a $10 \mathrm{~mL}$ test tube after incubating at room temperature for $3 \mathrm{~min}$. After adding of $4 \mathrm{~mL}$ saturated sodium carbonate $\left(75 \mathrm{~g} \mathrm{~L}^{-1}\right)(\mathrm{Merck}, 106392)$ and keeping it under room temperature for $90 \mathrm{~min}$, the absorbance value of final mixture were read by a spectrophotometer (Shimadzu) at $765 \mathrm{~nm}$ wavelength. The results were expressed as $\mathrm{mg}$ of gallic acid equivalent per $100 \mathrm{~g}$ of fresh weight (mg GAE $100 \mathrm{~g}^{-1} \mathrm{fw}$ ).

The antioxidant activity was determined according to Benvenuti et al (2004) and Sánchez-Moreno et al (1999) with some modifications. A six hundred $\mu \mathrm{L}$ 2,2-diphenyl-1-picrylhydrazyl (DPPH) (Sigma, D9132) solution was added in 5 test tubes and 20,40,60, 80 and $100 \mu \mathrm{L}$ of diluted pomegranate juice were added to these tubes, respectively. They were completed to $6 \mathrm{~mL}$ with methanol (Sigma, 34860) and throughly mixed with vortex. Then they were incubated for $15 \mathrm{~min}$ in the dark. Absorbance values at $517 \mathrm{~nm}$ of these solutions were determined via spectrophotometer (Shimadzu). The \% inhibition values corresponding to each sample volume were calculated and after plotting them against sample volumes, the curve was drawn for each sample by linear regression analysis. Using the regression equation and dilution factor, $\mathrm{EC}_{50}$ (efficient concentration) values were calculated. This value refers to the concentration of the antioxidant substance that inhibits $50 \%$ of the DPPH radical. The lowest $\mathrm{EC}_{50}$ value means highest antioxidant activity (Olugbami et al 2015).

\subsection{Statistical analysis}

This study was set according to completely randomized experimental design with 4 replications and randomly selected 4 fruit were included in each replication. Analysis of Variance (ANOVA) was performed on the data by Minitab software (MINITAB 17 Inc., trial version) at $\mathrm{P} \leq 0.05$ error level. Means were compared by Tukey's test by MSTAT-C (Michigan State University, MI, USA) software and differences among means at $\mathrm{P} \leq 0.05$ error level were marked with letters. ArcSin transformations were applied to data of weight loss and chilling injury rate which were calculated as percentage.

\section{Results and Discussion}

\subsection{Skin and aril color}

Like other fruit species, fruit skin color is accepted as the most attractive property in pomegranate fruit, as well. In this experiment fruit skin $L^{*}$ and $h^{\circ}$ values mostly changed by the storage period $(\mathrm{P}=0.000)$ (Table 1). After a storage period of 120 days, the lowest $L^{*}(44.77)$ and $h^{\circ}\left(28.22^{\circ}\right)$ values were measured on the fruit skin. Similar trend were also observed in skin $C^{*}$ values and compared to the harvest time (47.62), the lowest $C^{*}(42.41)$ value were determined at the end of storage period. Similar changes in these parameters were also reported by Selcuk \& Erkan (2015) and Koyuncu et al (2019) for the fruit of the same cultivar. In the current study, significant effect of postharvest salicylic acid treatments was considerable for only skin $C^{*}$ values (Table 1). It was observed that SA2 treatment included fruit having the highest $C^{*}$ values $(\mathrm{P} \leq 0.05)($ Table 2$)$. As generally known that $C^{*}$ values present saturation level of a color and the higher $C^{*}$ values refers the better saturated and the more attractive color. Similarly, Koyuncu et al (2019) determined higher $C^{*}$ values in SA treated fruit compared to the controls. But the same researchers also mentioned that putrescine treatments were more successful to maintain higher $C^{*}$ values in fruit of 'Hicaznar' cultivar than salicylic acid at the end of the controlled atmosphere storage of 6 months. 
Table 1- Results of variance analyzes

\begin{tabular}{|c|c|c|c|}
\hline \multirow{2}{*}{ Assessments } & \multicolumn{3}{|l|}{ Factors } \\
\hline & $S P^{l}$ & $T^{l}$ & $S P \times T^{l}$ \\
\hline Skin $L^{*}$ & $0.000 * * * 2$ & $0.151 \mathrm{~ns}^{3}$ & $0.625 \mathrm{~ns}$ \\
\hline Skin $C^{*}$ & $0.000 * * *$ & $0.010 * *$ & $0.365 \mathrm{~ns}$ \\
\hline Skin $h^{\circ}$ & $0.000 * * *$ & $0.706 \mathrm{~ns}$ & $0.991 \mathrm{~ns}$ \\
\hline Aril $L^{*}$ & $0.016 *$ & $0.066 \mathrm{~ns}$ & $0.428 \mathrm{~ns}$ \\
\hline Aril $C^{*}$ & $0.000 * * *$ & $0.007 * *$ & $0.331 \mathrm{~ns}$ \\
\hline Aril $h^{\circ}$ & $0.000 * * *$ & $0.431 \mathrm{~ns}$ & $0.892 \mathrm{~ns}$ \\
\hline $\mathrm{SSC}(\%)$ & $0.000 * * *$ & $0.000 * * *$ & $0.000 * * *$ \\
\hline TA (citric acid \%) & $0.000 * * *$ & $0.003 * *$ & $0.059 \mathrm{~ns}$ \\
\hline Weight loss (\% and angle) & $0.000 * * *$ & $0.000 * * *$ & $0.001 * * *$ \\
\hline Chilling injury ( $\%$ and angle) & $0.000 * * *$ & $0.000 * * *$ & $0.000 * * *$ \\
\hline Total phenolics content (mg GAE $100 \mathrm{~g}^{-1} \mathrm{fw}$ ) & $0.000 * * *$ & $0.956 \mathrm{~ns}$ & $0.996 \mathrm{~ns}$ \\
\hline Antioxidant activity (mL g DPPH) & $0.000 * * *$ & $0.516 \mathrm{~ns}$ & $0.337 \mathrm{~ns}$ \\
\hline
\end{tabular}

${ }^{1} \mathrm{SP}$, storage period $\left(0^{\text {th }}, 60^{\text {th }}, 120^{\text {th }}\right.$ days $) ; \mathrm{T}$, treatments $(\mathrm{C} 1, \mathrm{C} 2, \mathrm{SA} 1, \mathrm{SA} 2) ; \mathrm{SP} \times \mathrm{T}$, Storage period $\mathrm{x}$ treatments interactions; ${ }^{2} *, \mathrm{P} \leq 0.05 ; * *, \mathrm{P} \leq 0.01$; ****, $\mathrm{P} \leq 0.001 ;{ }^{3} \mathrm{~ns}$, non-significant

$L^{*}, h^{\circ}$ and $C^{*}$ values of arils decreased depending on storage periods $(\mathrm{P} \leq 0.05)$ (Table 1$)$ and the lowest values were determined at the end of the storage period (Table 2). Similar results have been previously reported for 'Hicaznar' cultivar (Selcuk \& Erkan 2015; Candir et al 2018; Koyuncu et al 2019). On the other hand, treatments were significantly affected these data in our study $(\mathrm{P}=0.000)$ (Table 1). Fruit in $\mathrm{C} 1$ group had lowest aril $C^{*}$ values than the others. Within $\mathrm{C} 2, \mathrm{SA} 1$ and SA2 groups which had similar values, fruit treated with SA2 (22.83) showed significantly higher values (Table 2). On the other hand, Vatanparast et al (2012) did not find significant effect of SA treatment on $C^{*}$ values of arils in 'Malas Yazdi' pomegranate cultivar. This result could show that the effect of salicylic acid treatments on aril color may be depended on cultivar and/or ecology characteristics during fruit growth.

Table 2- The effect of storage period (SP) and treatments (Ts) on skin and aril color in 'Hicaznar' pomegranate fruit

\begin{tabular}{|c|c|c|c|c|c|c|}
\hline \multirow{2}{*}{ Factors } & \multicolumn{6}{|l|}{ Assessments } \\
\hline & Skin $L^{*}$ & Skin $C^{*}$ & Skin $h^{\circ}$ & Aril L* & Aril $C^{*}$ & Aril $h^{\circ}$ \\
\hline \multicolumn{7}{|l|}{$S P$} \\
\hline 0 & $53.46 \pm 0.48 \mathrm{a}^{1}$ & $47.62 \pm 0.19 \mathrm{a}^{1}$ & $33.74 \pm 0.74 \mathrm{a}^{1}$ & $26.74 \pm 0.26 \mathrm{a}^{1}$ & $24.49 \pm 0.36 \mathrm{a}^{1}$ & $24.51 \pm 0.40 \mathrm{a}^{1}$ \\
\hline 60 & $46.65 \pm 0.62 \mathrm{~b}$ & $44.00 \pm 0.51 \mathrm{~b}$ & $28.57 \pm 0.55 \mathrm{~b}$ & $27.29 \pm 0.49 \mathrm{a}$ & $21.54 \pm 0.38 b$ & $19.50 \pm 0.73 \mathrm{a}$ \\
\hline 120 & $44.77 \pm 0.69 \mathrm{c}$ & $42.41 \pm 0.58 \mathrm{c}$ & $28.22 \pm 0.54 \mathrm{~b}$ & $25.06 \pm 0.80 \mathrm{~b}$ & $20.52 \pm 0.37 \mathrm{c}$ & $19.95 \pm 0.47 \mathrm{~b}$ \\
\hline \multicolumn{7}{|l|}{$T s$} \\
\hline $\mathrm{C} 1$ & $47.33 \pm 1.52$ & $44.67 \pm 0.84 b^{2}$ & $29.70 \pm 1.17$ & $25.06 \pm 0.49$ & $21.03 \pm 0.86 b^{2}$ & $21.07 \pm 0.95$ \\
\hline $\mathrm{C} 2$ & $49.06 \pm 1.19$ & $43.70 \pm 0.89 \mathrm{~b}$ & $30.81 \pm 0.90$ & $27.02 \pm 0.63$ & $22.15 \pm 0.59 \mathrm{a}$ & $22.26 \pm 1.03$ \\
\hline SA1 & $47.63 \pm 1.33$ & $44.29 \pm 0.75 \mathrm{~b}$ & $29.77 \pm 1.08$ & $27.27 \pm 0.26$ & $22.72 \pm 0.48 \mathrm{a}$ & $21.21 \pm 0.80$ \\
\hline SA2 & $49.16 \pm 1.14$ & $46.06 \pm 0.72 \mathrm{a}$ & $30.42 \pm 0.99$ & $26.11 \pm 1.05$ & $22.83 \pm 0.51 \mathrm{a}$ & $20.76 \pm 0.88$ \\
\hline \multicolumn{7}{|l|}{$S P \times T s$} \\
\hline $0 \times \mathrm{C} 1$ & $53.46 \pm 1.08$ & $47.62 \pm 0.44$ & $33.74 \pm 1.65$ & $26.74 \pm 0.59$ & $24.49 \pm 0.80$ & $24.51 \pm 0.91$ \\
\hline $0 \times \mathrm{C} 2$ & $53.46 \pm 1.08$ & $47.62 \pm 0.44$ & $33.74 \pm 1.65$ & $26.74 \pm 0.59$ & $24.49 \pm 0.80$ & $24.51 \pm 0.91$ \\
\hline $0 \times \mathrm{SA} 1$ & $53.46 \pm 1.08$ & $47.62 \pm 0.44$ & $33.74 \pm 1.65$ & $26.74 \pm 0.59$ & $24.49 \pm 0.80$ & $24.51 \pm 0.91$ \\
\hline $0 \times \mathrm{SA} 2$ & $53.46 \pm 1.08$ & $47.62 \pm 0.44$ & $33.74 \pm 1.65$ & $26.74 \pm 0.59$ & $24.49 \pm 0.80$ & $24.51 \pm 0.91$ \\
\hline $60 \times C 1$ & $45.98 \pm 1.62$ & $44.16 \pm 0.96$ & $27.74 \pm 1.41$ & $25.24 \pm 0.24$ & $19.82 \pm 0.84$ & $18.75 \pm 1.67$ \\
\hline $60 \times \mathrm{C} 2$ & $47.96 \pm 0.78$ & $42.58 \pm 0.47$ & $29.40 \pm 0.91$ & $28.69 \pm 1.40$ & $21.47 \pm 0.40$ & $21.53 \pm 2.21$ \\
\hline $60 \times$ SA1 & $45.38 \pm 0.80$ & $43.34 \pm 0.30$ & $27.95 \pm 1.30$ & $27.78 \pm 0.31$ & $22.48 \pm 0.26$ & $19.22 \pm 0.70$ \\
\hline $60 \times \mathrm{SA} 2$ & $47.28 \pm 1.56$ & $45.93 \pm 1.39$ & $29.19 \pm 0.99$ & $27.48 \pm 0.72$ & $22.39 \pm 0.63$ & $18.52 \pm 0.76$ \\
\hline $120 \times \mathrm{C} 1$ & $42.55 \pm 1.01$ & $42.25 \pm 1.32$ & $27.64 \pm 1.47$ & $23.22 \pm 0.40$ & $18.79 \pm 0.80$ & $19.94 \pm 0.54$ \\
\hline $120 \times \mathrm{C} 2$ & $45.75 \pm 1.85$ & $40.89 \pm 0.50$ & $29.29 \pm 1.08$ & $25.65 \pm 0.71$ & $20.49 \pm 0.45$ & $20.74 \pm 1.84$ \\
\hline 120 x SA1 & $44.05 \pm 0.70$ & $41.90 \pm 0.36$ & $27.62 \pm 0.76$ & $27.30 \pm 0.34$ & $21.20 \pm 0.14$ & $19.89 \pm 0.55$ \\
\hline $120 \times \mathrm{SA} 2$ & $46.73 \pm 1.16$ & $44.62 \pm 1.45$ & $28.33 \pm 1.21$ & $24.09 \pm 3.00$ & $21.60 \pm 0.60$ & $19.25 \pm 0.37$ \\
\hline
\end{tabular}

${ }^{1}$ Letters represent the differences between average values belonging each storage period at $\mathrm{P} \leq 0.05$ error level; ${ }^{2}$ Letters represent the differences between average values belonging each treatment at $\mathrm{P} \leq 0.05$ error level 


\subsection{Soluble solids content}

Storage period and salicylic acid treatments interactively affected SSC of fruit $(\mathrm{P}=0.000)$ (Table 1). This parameter tended to decrease by cold storage period and reached lowest values at the end of storage period ( $120^{\text {th }}$ day) in all treatments. Similar results were reported in air-stored 'Mollar' and CA-stored 'Hicaznar' fruit (Artes et al 1998; Koyuncu et al 2019). Fruit in SA1 (17.15\%) and SA2 (17.15\%) groups showed significantly highest SSC on the $120^{\text {th }}$ day of storage period (Table 3). It means that these treatments helped to keep SSC level in fruit during 120 days. However in some other studies with 'Malas Saveh' and 'Shishe-kab' cultivars, SA treatments were not effective on SSC of fruit (Sayyari et al 2009; Moradinezhad \& Khayyat 2014).

\subsection{Titratable acidity content}

TA is one of the major quality characteristics of pomegranate fruit and citric acid is the dominant organic acid in fruit of 'Hicaznar' cultivar (Selcuk \& Erkan 2015). In the current study, significant losses in TA levels were observed during storage period, and the lowest mean value was measured at the end of storage period in fruit of 'Hicaznar' cultivar $(\mathrm{P} \leq 0.05)$ (Table 1 and 3). According to Selcuk \& Erkan (2015), decrease in TA during storage period of pomegranate fruit resulted from fruit respiration because organic acids are mostly consumed components throughout respiration pathway. Our results are in accordance with those obtained by Shaarawi et al (2016) in fruit of 'Wonderful'. In the current study, SA1 and SA2 treatments were effective on keeping TA content of fruit during cold storage period of 120 days (Table 3). Koyuncu et al (2019) stated that SA treatment is effective for maintaining the TA level in fruit of 'Hicaznar' cultivar during controlled atmosphere storage of 6 months. However, Sayyari et al (2009) mentioned opposite results in fruit of 'Malas Saveh' cultivar during cold storage.

\subsection{Weight loss}

Weight loss in pomegranate fruit during storage is mostly due to the fact that a high porosity of the fruit skin (Elyatem \& Kader 1984). In our study, storage period and salicylic acid treatments interactively effected weight loss in fruit of 'Hicaznar' $(\mathrm{P}=0.000)$ (Table 1). In all groups, this parameter increased through storage period and significantly highest values were determined at the end of cold storage period of 120 days compared to the harvest time. At the end of the $120^{\text {th }}$ day, while fruit in C1 (4.55\%) and SA1 (4.21\%) had higher weight loss values, fruit in C2 (2.70\%) and SA2 (3.59\%) groups showed lower weight loss levels (Table 3). It seems that SA2 also helped to prevent weight loss in fruit compared to untreated fruit (C1). Similar finding was reported by Koyuncu et al (2019). According to the researchers, 2 mM SA treatment decreased weight loss at a rate of $2.76 \%$ in fruit of 'Hicaznar' cultivar during controlled atmosphere storage of 6 months. On the other hand, Moradinezhad \& Khayyat (2014) reported that 2 mM SA treatment did not have a significant effect on weight loss levels of 'Shishe-Kab' fruit during cold storage period. This can be resulted from differences in fruit skin structure with regard to porosity in different cultivars.

\subsection{Chilling injury}

It is conversant that chilling injury (CI) in pomegranate fruit is defined by membrane breakdown resulting in loss of tissue completeness companied by skin browning (Sayyari et al 2017). In fruit of different pomegranate cultivars, such as 'Wonderful' or 'Malas Saveh', CI symptoms like browning of skin, arils and membrane were observed, when they were stored at temperatures lower than 5 or $6{ }^{\circ} \mathrm{C}$ depending on the cultivars (Defilippi et al 2006; Sayyari et al 2009). In our study, the significant effect of storage periods $\mathrm{x}$ treatments interactions on CI was determined $(\mathrm{P}=0.000)(\mathrm{Table} 1)$ and CI was firstly observed at the end of the cold storage period (Table 3$)$. In control groups (C1 and $\mathrm{C} 2,62.50 \%)$, more than half of the fruit showed CI symptoms and fruit loss was the highest in these groups. Fruit in SA2 group were more resistant to the storage temperature and had the lowest CI rate as $12.50 \%$. It seems that $4 \mathrm{mM} \mathrm{SA}$ treatment helped to improve fruit tolerance to low temperature. Similarly, in some studies (Moradinezhad \& Khayyat 2014; Sayyari et al 2011 and 2017), it was indicated that postharvest SA treatments reduced CI in fruit of 'Shishe-kab' and 'Mollar' cultivars. Koyuncu et al (2019) observed any CI symptoms in SA-treated 'Hicaznar' fruit during controlled atmosphere storage of 6 months because they stored fruit at $6{ }^{\circ} \mathrm{C}$ and this temperature was $1{ }^{\circ} \mathrm{C}$ higher than our storage temperature. Current results showed once more the importance of storage temperature in pomegranate fruit and lower temperature of $1{ }^{\circ} \mathrm{C}$ could increase fruit loss because of CI. 
Table 3- The effect of storage period (SP) and treatments (Ts) on some quality assessments in 'Hicaznar' pomegranate fruit

\begin{tabular}{|c|c|c|c|c|c|c|}
\hline \multirow[b]{2}{*}{ Factors } & \multicolumn{6}{|l|}{ Assessments } \\
\hline & $\begin{array}{l}S S C^{l} \\
(\%)\end{array}$ & $\begin{array}{l}T A^{l} \\
\text { (citric acid \%) }\end{array}$ & $\begin{array}{l}W L^{l} \\
(\%)\end{array}$ & $\begin{array}{l}C^{I} \\
(\%)\end{array}$ & $\begin{array}{l}T P C^{I} \\
\left(m g G A E 100 g^{-1}\right)\end{array}$ & $\begin{array}{l}A A^{l} \\
\left(m L g^{-1} D P P H\right)\end{array}$ \\
\hline \multicolumn{7}{|l|}{$S P$ (days) } \\
\hline 0 & $17.50 \pm 0.00$ & $1.96 \pm 0.00 \mathrm{a}^{2}$ & $0.00 \pm 0.00$ & $0.00 \pm 0.00$ & $230.51 \pm 1.25 \mathrm{c}^{2}$ & $55.61 \pm 0.59 \mathrm{c}^{2}$ \\
\hline 60 & $17.44 \pm 0.01$ & $1.69 \pm 0.00 \mathrm{~b}$ & $1.97 \pm 0.17$ & $0.00 \pm 0.00$ & $260.78 \pm 1.27 \mathrm{a}$ & $59.84 \pm 1.33 b$ \\
\hline 120 & $17.01 \pm 0.04$ & $1.49 \pm 0.00 \mathrm{c}$ & $3.76 \pm 0.23$ & $42.19 \pm 6.34$ & $250.22 \pm 1.35 \mathrm{~b}$ & $68.68 \pm 1.80 \mathrm{a}$ \\
\hline \multicolumn{7}{|l|}{$T s$} \\
\hline $\mathrm{C} 1$ & $17.24 \pm 0.09$ & $1.69 \pm 0.05 \mathrm{c}^{3}$ & $2.34 \pm 0.66$ & $20.83 \pm 9.15$ & $246.55 \pm 3.95$ & $61.05 \pm 1.61$ \\
\hline $\mathrm{C} 2$ & $17.28 \pm 0.08$ & $1.71 \pm 0.06 \mathrm{bc}$ & $1.29 \pm 0.40$ & $20.83 \pm 9.15$ & $247.03 \pm 3.99$ & $62.76 \pm 2.73$ \\
\hline SA1 & $17.36 \pm 0.04$ & $1.74 \pm 0.05 \mathrm{a}$ & $2.20 \pm 0.61$ & $10.42 \pm 4.82$ & $247.84 \pm 3.94$ & $62.06 \pm 2.53$ \\
\hline SA2 & $17.38 \pm 0.04$ & $1.72 \pm 0.05 \mathrm{ab}$ & $1.79 \pm 0.52$ & $4.17 \pm 2.81$ & $247.25 \pm 4.38$ & $59.65 \pm 1.89$ \\
\hline \multicolumn{7}{|l|}{$S P \times T s$} \\
\hline $0 \times \mathrm{C} 1$ & $17.50 \pm 0.00 \mathrm{a}, \mathrm{a}^{4}$ & $1.92 \pm 0.00$ & $\begin{array}{l}0.00 \pm 0.00 \\
(0.00 \pm 0.00)^{5} \mathrm{c}, \mathrm{a}^{4}\end{array}$ & $\begin{array}{l}0.00 \pm 0.00 \\
(0.00 \pm 0.00)^{5} b, a^{4}\end{array}$ & $230.28 \pm 2.51$ & $55.40 \pm 0.37$ \\
\hline $0 \times \mathrm{C} 2$ & $17.50 \pm 0.00 \mathrm{a}, \mathrm{a}$ & $1.92 \pm 0.00$ & $\begin{array}{l}0.00 \pm 0.00 \\
(0.00 \pm 0.00) \quad \text { c, a }\end{array}$ & $\begin{array}{l}0.00 \pm 0.00 \\
(0.00 \pm 0.00) \quad b, a\end{array}$ & $230.95 \pm 3.65$ & $55.73 \pm 1.42$ \\
\hline $0 \times \mathrm{SA} 1$ & $17.50 \pm 0.00 \mathrm{a}, \mathrm{a}$ & $1.92 \pm 0.00$ & $\begin{array}{l}0.00 \pm 0.00 \\
(0.00 \pm 0.00) \quad \text { c, a }\end{array}$ & $\begin{array}{l}0.00 \pm 0.00 \\
(0.00 \pm 0.00) \quad b, a\end{array}$ & $231.57 \pm 1.50$ & $55.92 \pm 0.89$ \\
\hline $0 \times \mathrm{SA} 2$ & $17.50 \pm 0.00 \mathrm{a}, \mathrm{a}$ & $1.92 \pm 0.00$ & $\begin{array}{l}0.00 \pm 0.00 \\
(0.00 \pm 0.00) \quad \text { c, a }\end{array}$ & $\begin{array}{l}0.00 \pm 0.00 \\
(0.00 \pm 0.00) \quad b, a\end{array}$ & $229.23 \pm 2.87$ & $55.40 \pm 2.01$ \\
\hline $60 \times \mathrm{C} 1$ & $17.40 \pm 0.04 \mathrm{~b}, \mathrm{a}$ & $1.69 \pm 0.01$ & $\begin{array}{l}2.48 \pm 0.16 \\
(9.05 \pm 0.29) \quad b, a\end{array}$ & $\begin{array}{l}0.00 \pm 0.00 \\
(0.00 \pm 0.00) \quad b, a\end{array}$ & $260.53 \pm 0.86$ & $61.37 \pm 0.65$ \\
\hline $60 \times \mathrm{C} 2$ & $17.45 \pm 0.02 \mathrm{a}, \mathrm{a}$ & $1.66 \pm 0.01$ & $\begin{array}{l}1.18 \pm 0.20 \\
(6.19 \pm 0.56) \quad b, c\end{array}$ & $\begin{array}{l}0.00 \pm 0.00 \\
(0.00 \pm 0.00) \quad b, a\end{array}$ & $260.32 \pm 3.55$ & $58.98 \pm 3.45$ \\
\hline $120 \times \mathrm{C} 1$ & $16.82 \pm 0.02 \mathrm{c}, \mathrm{c}$ & $1.47 \pm 0.00$ & $\begin{array}{l}4.55 \pm 0.19 \\
(12.31 \pm 0.25) \text { a, a }\end{array}$ & $\begin{array}{l}62.50 \pm 7.22 \\
(52.50 \pm 4.33) a, a\end{array}$ & $248.85 \pm 3.09$ & $66.38 \pm 2.79$ \\
\hline $120 \times \mathrm{C} 2$ & $16.90 \pm 0.04 \mathrm{~b}, \mathrm{~b}$ & $1.48 \pm 0.00$ & $\begin{array}{l}2.70 \pm 0.24 \\
(9.44 \pm 0.45) \quad \text { a, c }\end{array}$ & $\begin{array}{l}62.50 \pm 7.22 \\
(52.50 \pm 4.33) a, a\end{array}$ & $249.82 \pm 1.17$ & $73.57 \pm 2.80$ \\
\hline 120 x SA1 & $17.15 \pm 0.02 \mathrm{~b}, \mathrm{a}$ & $1.52 \pm 0.02$ & $\begin{array}{l}4.21 \pm 0.23 \\
(11.83 \pm 0.34) \mathrm{a}, \mathrm{a}\end{array}$ & $\begin{array}{l}31.25 \pm 6.25 \\
(33.75 \pm 3.75) a, b\end{array}$ & $251.25 \pm 2.95$ & $71.25 \pm 2.87$ \\
\hline $120 \times \mathrm{SA} 2$ & $17.17 \pm 0.02 \mathrm{~b}, \mathrm{a}$ & $1.51 \pm 0.02$ & $\begin{array}{l}3.59 \pm 0.32 \\
(10.90 \pm 0.48) a, b\end{array}$ & $\begin{array}{l}12.50 \pm 7.22 \\
(15.00 \pm 8.66) \mathrm{a}, \mathrm{c}\end{array}$ & $250.95 \pm 3.95$ & $63.53 \pm 4.48$ \\
\hline
\end{tabular}

${ }^{1}$ SSC, Soluble solids content; TA, Titratable acidity; WL, Weight loss; CI, Chilling Injury; TPC, Total phenolic content; AA, Antioxidant activity; ${ }^{2}$ Letters represent the differences between average values belonging each storage period at $\mathrm{P} \leq 0.05$ error level; ${ }^{3}$ Letters represent the differences between average values belonging each treatment at $\mathrm{P} \leq 0.05$ error level; ${ }^{4}$ The first letters represent the differences between storage periods for each treatment and the second letters represent the differences between treatments for each storage period at $\mathrm{P} \leq 0.05$ error level; ${ }^{5}$ Arcsin transformation values of percentage data

\subsection{Total phenolic content and antioxidant activity}

TPC and AA are responsible for the most part of health benefits in pomegranate arils. So, maintaining of these parameters during postharvest period is important for not only consumers but also retailers. In the current study, it was revealed that the major effective factor on keeping of these parameters after harvest was storage period and none of postharvest salicylic acid treatments showed significant effect on these parameters $(\mathrm{P}=0.000)$ (Table 1 and 3). Our results are in agreement with Sayyari et al (2011) in 'Mollar de Elche' cultivar and Koyuncu et al (2019) who mentioned no differences among controls and SA-treated 'Hicaznar' fruit in respect of total phenolic content. In contrast, Dokhanieh et al (2016) stated that $250 \mu \mathrm{M}$ SA treatment delayed decrease in total phenolics during storage period in 'Malase Yazd' fresh cut pomegranates. In the current study, either TPC or AA content in fruit increased during storage period and generally, the higher values were determined at the end of the whole storage period when compared to harvest time. It is known that increase in phenolic compounds of fruit during cold storage was arisen from different stress conditions (Selcuk \& Erkan 2015). It can be said that low temperature at $5{ }^{\circ} \mathrm{C}$, as a stress condition; caused increase in these two parameters at the end of storage period. Similar results were obtained in pomegranate cultivars such as 'Hicaznar' (Selcuk \& Erkan 2015; Candir et al 2018; Koyuncu et al 2019), 'Wonderful' (Arendse et al 2014), 'Malase Saveh' (Babalar et al 2018). However, the effect of stress conditions on TPC could change based on cultivars. Thus, significant reductions in TPC were 
determined in some studies during whole cold storage period in 'Mollar de Elche' (Sayyari et al 2011; Sayyari et al 2017), and 'Malase Yazd' (Dokhaineh et al 2016) cultivars.

\section{Conclusions}

This study highlights effects of SA treatments at different concentrations on some postharvest quality parameters, TPC and AA in fruit of 'Hicaznar' pomegranate cultivar during cold storage period. SA treatments helped to maintain $C^{*}$ values in arils and skin, TA and SSC content, and especially $4 \mathrm{mM}$ concentration reduced CI symptoms during cold storage period of 120 days. Conversely, this treatment has not been effective on TPC and AA. Overall, $0.01 \%$ Tween $20+4 \mathrm{mM}$ SA dipping for $10 \mathrm{~min}$ at $20^{\circ} \mathrm{C}$ could be a promising treatment for fruit of 'Hicaznar' cultivar grown in MersinTarsus region in respect of keeping most of quality parameters.

\section{References}

Arendse E, Fawole O A \& Opara U L (2014). Effects of postharvest storage conditions on phytochemical and radical-scavenging activity of pomegranate fruit (cv. Wonderful). Scientia Horticulturae 169: 125-129

Artes F, Tudela J A \& Gil M I (1998). Improving the keeping quality of pomegranate fruit by intermittent warming. Zeitschrift für Lebensmitteluntersuchung und Forschung 207: 316-321

Asghari M \& Aghdam M S (2010). Impact of salicylic acid on postharvest physiology of horticultural crops. Trends in Food Science and Technology 2: 502-509

Aviram M, Dornfeld L, Rosenblat M, Volkova N, Kaplan M, Coleman R, Hayek T, Presser D \& Fuhrman B (2000). Pomegranate juice consumption reduces oxidative stress, atherogenic modifications to LDL, and platelet aggregation: studies in humans and in atherosclerotic apolipoprotein E-deficient mice. The American Journal of Clinical Nutrition 71(5): 1062-1076

Babalar M, Pirzad F, Sarcheshmeh M A A, Talaei A \& Lessani H (2018). Arginine treatment attenuates chilling injury of pomegranate fruit during cold storage by enhancing antioxidant system activity. Postharvest Biology and Technology 137: 31-37

Benvenuti S, Pellati F, Melegari M \& Bertelli D (2004). Polyphenols, anthocyanins, ascorbic acid, and radical scavenging activity of Rubus, Ribes, and Aronia. Journal of Food Science 69(3): 164-169

Candir E, Ozdemir A E \& Aksoy M C (2018). Effects of chitosan coating and modified atmosphere packaging on postharvest quality and bioactive compounds of pomegranate fruit cv. 'Hicaznar'. Scientia Horticulturae 235: 235-243

Chan Z L \& Tian S (2006). Induction of $\mathrm{H}_{2} \mathrm{O}_{2}$-metabolizing enzymes and total protein synthesis by antagonistic yeast and salicylic acid in harvested sweet cherry fruit. Postharvest Biology and Technology 39(3): 314-320

Defilippi B G, Whitaker B D, Hess-Pierce B M \& Kader A A (2006). Development and control of scald on wonderful pomegranates during long-term storage. Postharvest Biology and Technology 41(3): 234-243

Dokhanieh A Y, Aghdam M S \& Sarcheshmeh M A A (2016). Impact of postharvest hot salicylic acid treatment on aril browning and nutritional quality in fresh-cut pomegranate. Horticulture, Environment, and Biotechnology 57(4): 378-384

Elyatem S M \& Kader A A (1984). Post-harvest physiology and storage behaviour of pomegranate fruits. Scientia Horticulturae 24(34): $287-298$

Kader A A (2006). Postharvest biology and technology of pomegranates. In: Seeram N P, Schulman R N \& Heber D (Eds.), Pomegranates: Ancient Roots to Modern Medicine, CRC Press, Boca Raton, FL, pp. 211-220

Kader A A, Chordas A \& Elyatem S (1984). Responses of pomegranates to ethylene treatment and storage temperature. California Agriculture 38(7): 4-15

Koyuncu M A, Erbas D, Onursal C E, Secmen T, Guneyli A \& Uzumcu S S (2019). Postharvest treatments of salicylic acid, oxalic acid and putrescine influences bioactive compounds and quality of pomegranate during controlled atmosphere storage. Journal of Food Science and Technology 56(1): 350-359

Köksal A I (1989). Research on the storage of pomegranate (cv. Gök Bahçe) under different conditions. Acta Horticulturae 258: 295302

Journal of Agricultural Sciences (Tarım Bilimleri Dergisi) 26 (2020) 499-506 
McGuire R G (1992). Reporting of objective color measurements. HortScience 27(12): 1254-1255

Mirdehghan S H, Rahemi M, Martínez-Romero D, Guillén F, Valverde J M, Zapata P J, Serrano M \& Valero D (2007). Reduction of pomegranate chilling injury during storage after heat treatment: Role of polyamines. Postharvest Biology and Technology 44(1): $19-25$

Moradinezhad F \& Khayyat M (2014). Effects of intermittent warming and prestorage treatments (Hot water, salicylic acid, calcium chloride) on postharvest life of pomegranate fruit cv. 'Shishe-kab' during long-term cold storage. International Journal of Horticultural Science and Technology 1(1): 43-51

Olugbami J O, Gbadegesin M A \& Odunola O A (2015). In vitro free radical scavenging and antioxidant properties of ethanol extract of Terminalia glaucescens. Pharmacognosy Research 7(1): 49-56

Raskin I (1992). The role of salicylic acid in plants. Annual Review of Plant Physiology and Plant Molecular Biology 43: 439-463

Sánchez-Moreno C, Larrauri J A \& Saura-Calixto F (1999). Free radical scavenging capacity of selected red, rose and white wines. The Journal of the Science of Food and Agriculture 79(10): 1301-1304

Sayyari M, Babalar M, Kalantari S, Serrano M \& Valero M (2009). Effect of salicylic acid treatment on reducing chilling injury in stored pomegranates. Postharvest Biology and Technology 53(3): 152-154

Sayyari M, Valero D, Babalar M, Kalantari S, Zapata P J \& Serrano M (2010). Prestorage oxalic acid treatment maintained visual quality, bioactive compounds, and antioxidant potential of pomegranate after long-term storage at $2{ }^{\circ} \mathrm{C}$. Journal of Agricultural and Food Chemistry 58(11): 6804-6808

Sayyari M, Babalar M, Kalantari S, Martínez-Romero D, Guillén F, Serrano M \& Valero D (2011). Vapour treatments with methyl salicylate or methyl jasmonate alleviated chilling injury and enhanced antioxidant potential during postharvest storage of pomegranates. Food Chemistry 124(3): 964-970

Sayyari M, Valero D \& Serrano M (2017). Pre-storage salicylic acid treatment affects functional properties, unsaturated/saturated fatty acids ratio and chilling resistance of pomegranate during cold storage. International Food Research Journal 24(2): 637-642

Selcuk N \& Erkan M (2015). Changes in phenolic compounds and antioxidant activity of sour-sweet pomegranates cv. 'Hicaznar' during long-term storage under modified atmosphere packaging. Postharvest Biology and Technology 109(2015): 30-39

Shaarawi S A M A, Salem A S E, Elmaghraby I M K \& Abd El-Moniem E A A (2016). Effect of salicylic acid, calcium chloride and calcium lactate applications on quality attributes of minimally-processed 'Wonderful' pomegranate arils. Notulae Botanicae Horti Agrobotanici Cluj-Napoca 44(2): 508-517

Spanos G A \& Wrolstad R E (1990). Influence of processing, and storage on the phenolic composition of Thompson Seedless grape juice. Journal of Agricultural and Food Chemistry 38(7): 1565-1571

Srivastava M K \& Dwivedi U N (2000). Delayed ripening of banana fruit by salicylic acid. Plant Science 158(1-2): 87-96

Vatanparast G, Mirdehghan S H, Karimi H R \& Vazifeshenas M H (2012). Foliar application of salicylic acid, methyl jasmonate and potassium sulfate on photosynthetic characteristics and fruit quality of pomegranate. Iran Agricultural Research 31(2): 23-34

Wang L, Chen S, Kong W, Li S \& Archbold D D (2006). Salicylic acid pretreatment alleviates chilling injury and affects the antioxidant system and heat shock proteins of peaches during cold storage. Postharvest Biology and Technology 41(3): 244-251

Wang D, Özen C, Abu-Reidah I M, Chigurupati S, Patra J K, Horbanczuk J O, Jóźwik A, Tzvetkov N T, Uhrin P \& Atanasov A G (2018). Vasculoprotective effects of pomegranate (Punica granatum L.). Frontiers in Pharmacology 9: 544

Zhang Y, Chen K, Zhang S \& Ferguson I (2003). The role of salicylic acid in postharvest ripening of kiwifruit. Postharvest Biology and Technology 28(1): 67-74 